\title{
Clinical trial of pentazocine in rheumatoid arthritis
}

\section{Observations on the value of potent analgesics and placebos}

\author{
G. NUKI,* W. W. DOWNIE, W. C. DICK, K. WHALEY, J. B. SPOONER, $\dagger$ \\ M. A. DARBY-DOWMAN, $\dagger$ AND W. W. BUCHANAN \\ Centre for Rheumatic Diseases and University Department of Medicine, Royal Infirmary, Glasgow
}

Severe and chronic pain is a dominant feature in most patients with rheumatoid arthritis. Despite optimum doses of standard analgesic and anti-inflammatory drugs, there are many patients who do not obtain adequate pain relief. Until recently, the use of strong analgesics has been strongly contraindicated, as all such available drugs were classified under the Dangerous Drugs Act (Dudley Hart, 1968). The risk of drug dependence in patients with a chronic disease such as rheumatoid arthritis clearly precludes the use of such drugs except in exceptional circumstances. The development of a new group of narcotic antagonists with a benzomorphan nucleus (Archer, Albertson, Harris, Pierson, Bird, Keats, Telford, and Papadopoulos, 1962) led to the introduction of pentazocine in 1967. When given by intramuscular or subcutaneous injection, $30 \mathrm{mg}$. pentazocine is approximately equinanalgesic with $10 \mathrm{mg}$. morphine (British Medical Journal, Today's Drugs, 1970). The W.H.O. Expert Committee on Drug Dependence have passed pentazocine as being safe for use without special controls on three occasions (W.H.O. Technical Reports, 1966, 1969, 1970). It has been widely used for the relief of postoperative pain (Kantor, Sunshine, Laska, Meisner, and Hopper, 1966) in the management of patients with malignant disease (Beaver, Wallenstein, Houde, and Rogers, 1968; Frankendal and Kjellgren, 1971), ischaemic heart (Scott and Orr, 1969) and limb pain (Taylor, 1971), and in obstetric practice (Mitchell, 1963; Filler and Filler, 1966). In two uncontrolled trials (Vignon, Chapuy, and Falconnet, 1969; DavidChaussé and Laporte, 1970), it was suggested that injections of pentazocine in doses ranging from 30 to $120 \mathrm{mg}$. per day were highly effective in patients with a variety of rheumatic diseases. The marketing of an oral preparation in 1969 made it possible to consider the use of pentazocine as a practical possibility in the long-term management of rheumatoid arthritis, although it was found to be only one-third as effective 을 as the parenteral preparation on clinical assessment (Beaver, 1968) and on monitoring blood levels $\mathcal{D}$ (Beckett, Taylor, and Kourounakis, 1970).

In considering the use of pentazocine for the treatment of rheumatoid arthritis, it is unlikely that it would be an effective form of therapy on its own. It possesses no anti-inflammatory or antipyretic activit $\hat{\theta}$ (Sterling Winthrop Laboratories, Unpublished obs servations). Fremont-Smith and Bayles (196 showed that even large doses of pethidine were les $\vec{S}$ effective than salicylates in relieving symptoms in active rheumatoid arthritis, and it is generally accepted that, if adequate analgesia is to be obtained, drugs combining peripheral anti-inflammatory, analgesic, and antipyretic effects must be employed (Winter, 1966; Drug Ther. Bull., 1966).

In this paper, we report the results of a doubleblind cross-over trial in which oral pentazocine and identical placebo tablets were given to patients who were receiving standard and stable regimes of nonsteroidal analgesic anti-inflammatory drugs but were obtaining inadequate relief of pain.

\section{Material and methods}

PATIENTS STUDIED

Forty patients with 'definite' or 'classical' rheumatoid arthritis (Ropes, Bennett, Cobb, Jacox, and Jessar, 1959) were studied. All were out-patients attending the Centre for Rheumatic Diseases who complained of inadequate pain relief despite taking one or two standard nonsteroidal analgesic anti-inflammatory drugs in steady dosage for at least 1 month. Patients receiving corticosteroids, chrysotherapy, or antimalarial drugs were excluded. The purpose of the investigation was explained to each patient, a summary of whose clinical features is shown in Table $I$. 
Table I Clinical assessment and drug therapy in forty patients with rheumatoid arthritis

\begin{tabular}{|c|c|c|c|c|c|c|c|c|c|c|c|c|}
\hline \multirow[t]{2}{*}{$\begin{array}{l}\text { Patient } \\
\text { no. }\end{array}$} & \multirow[t]{2}{*}{$\begin{array}{l}\text { Age } \\
(y r s)\end{array}$} & \multirow[t]{2}{*}{ Sex } & \multirow{2}{*}{$\begin{array}{l}\text { Duration } \\
\text { of disease } \\
\text { (yrs) }\end{array}$} & \multirow[t]{2}{*}{$\begin{array}{l}\text { Radiological } \\
\text { stage }^{*}\end{array}$} & \multirow[t]{2}{*}{$\begin{array}{l}\text { Articular } \\
\text { index } \dagger\end{array}$} & \multicolumn{2}{|c|}{$\begin{array}{l}\text { Grip } \\
\text { strength } \\
(\mathrm{mm} . \mathrm{Hg})\end{array}$} & \multirow{2}{*}{$\begin{array}{l}\text { Pain } \\
\text { score } \\
(0-4) \ddagger\end{array}$} & \multirow{2}{*}{$\begin{array}{l}\text { Stiffness } \\
\text { score } \\
(0-4) \ddagger\end{array}$} & \multirow[t]{2}{*}{$\begin{array}{l}\text { Drug } \\
\text { therapy§ }\end{array}$} & \multirow{2}{*}{$\begin{array}{l}\text { Daily } \\
\text { dosage } \\
(g .)\end{array}$} & \multirow{2}{*}{$\begin{array}{l}\text { Order } \\
\text { of } \\
\text { adminis- } \\
\text { tration }\end{array}$} \\
\hline & & & & & & $R$ & $L$ & & & & & \\
\hline $\begin{array}{l}1 \\
2\end{array}$ & $\begin{array}{l}49 \\
63\end{array}$ & $\begin{array}{l}\mathbf{F} \\
\mathbf{M}\end{array}$ & $\begin{array}{l}3 \\
2\end{array}$ & ${ }_{\text {I II }}$ & $\begin{array}{l}59 \\
14\end{array}$ & $\begin{array}{l}60 \\
60\end{array}$ & $\begin{array}{l}60 \\
60\end{array}$ & $\begin{array}{l}4 \\
2\end{array}$ & $\begin{array}{l}4 \\
2\end{array}$ & FLU & $\begin{array}{l}0.6 \\
4.0\end{array}$ & $\begin{array}{l}\mathbf{A} \\
\mathbf{B}\end{array}$ \\
\hline 3 & 38 & $\mathbf{F}$ & 10 & III & 12 & 95 & 105 & 3 & 3 & $\left\{\begin{array}{l}\text { SAL } \\
\text { IND }\end{array}\right.$ & $\left.\begin{array}{c}4 \cdot 0 \\
0.3\end{array}\right\}$ & B \\
\hline $\begin{array}{l}4 \\
5\end{array}$ & $\begin{array}{l}58 \\
43\end{array}$ & $\begin{array}{l}\mathbf{M} \\
\mathbf{M}\end{array}$ & $\begin{array}{r}4 \\
17\end{array}$ & $\begin{array}{l}\text { III } \\
\text { III }\end{array}$ & $\begin{array}{r}9 \\
20\end{array}$ & $\begin{array}{r}150 \\
80\end{array}$ & $\begin{array}{r}180 \\
75\end{array}$ & $\begin{array}{l}2 \\
1\end{array}$ & $\begin{array}{l}4 \\
1\end{array}$ & IBU & $\begin{array}{l}1.6 \\
1.2\end{array}$ & $\begin{array}{l}\mathbf{A} \\
\mathbf{A}\end{array}$ \\
\hline 6 & 61 & $\mathbf{F}$ & 13 & IV & 64 & 50 & 50 & 3 & 3 & $\left\{\begin{array}{l}\text { IBU } \\
\text { IND }\end{array}\right.$ & $\begin{array}{l}1.2 \\
0.1\end{array}$ & B \\
\hline $\begin{array}{l}7 \\
8 \\
9\end{array}$ & $\begin{array}{l}46 \\
61 \\
52\end{array}$ & $\begin{array}{l}\mathbf{F} \\
\mathbf{F} \\
\mathbf{F}\end{array}$ & $\begin{array}{r}2 \\
7 \\
20\end{array}$ & $\begin{array}{l}\text { III } \\
\text { III } \\
\text { IV }\end{array}$ & $\begin{array}{l}66 \\
21 \\
10\end{array}$ & $\begin{array}{r}30 \\
150 \\
90\end{array}$ & $\begin{array}{r}30 \\
135 \\
80\end{array}$ & $\begin{array}{l}4 \\
3 \\
2\end{array}$ & $\begin{array}{l}4 \\
4 \\
2\end{array}$ & $\begin{array}{l}\text { ASP } \\
\text { IND } \\
\text { IBU }\end{array}$ & $\begin{array}{l}6 \cdot 0 \\
0 \cdot 1 \\
1 \cdot 2\end{array}$ & $\begin{array}{l}\mathbf{B} \\
\mathbf{B} \\
\mathbf{A}\end{array}$ \\
\hline 10 & 42 & $\mathbf{M}$ & 3 & I & 32 & 100 & 70 & 4 & 3 & $\left\{\begin{array}{l}\text { IBU } \\
\text { IND }\end{array}\right.$ & $\left.\begin{array}{l}1.2 \\
0.15\end{array}\right\}$ & A \\
\hline $\begin{array}{l}11 \\
12\end{array}$ & $\begin{array}{l}73 \\
52\end{array}$ & $\begin{array}{l}\mathbf{M} \\
\mathbf{F}\end{array}$ & $\begin{array}{l}3 \\
6\end{array}$ & $\begin{array}{l}\text { II } \\
\text { III }\end{array}$ & $\begin{array}{l}63 \\
21\end{array}$ & $\begin{array}{l}60 \\
60\end{array}$ & $\begin{array}{l}70 \\
70\end{array}$ & $\begin{array}{l}4 \\
2\end{array}$ & $\begin{array}{l}3 \\
3\end{array}$ & $\begin{array}{l}\text { MEF } \\
\text { IND }\end{array}$ & $\begin{array}{l}0.75 \\
0.075\end{array}$ & $\begin{array}{l}\mathbf{A} \\
\mathbf{B}\end{array}$ \\
\hline 13 & 34 & $\mathbf{F}$ & 2 & III & 8 & 100 & 100 & 4 & 4 & $\left\{\begin{array}{l}\text { ASP } \\
\text { IND }\end{array}\right.$ & $\left.\begin{array}{l}3.0 \\
0.1\end{array}\right\}$ & $\mathbf{A}$ \\
\hline 14 & 56 & $\mathbf{M}$ & 6 & III & 9 & 100 & 90 & 2 & 2 & IBU & 0.6 & B \\
\hline 15 & 67 & $\mathbf{F}$ & 2 & III & 20 & 65 & 70 & 4 & 4 & $\left\{\begin{array}{l}\text { IND } \\
\text { IBU }\end{array}\right.$ & $\begin{array}{l}0.075 \\
1.2\end{array}$ & $\mathbf{A}$ \\
\hline 16 & 41 & $\mathbf{F}$ & 1 & I & 25 & 70 & 60 & 2 & 2 & $\left\{\begin{array}{l}\text { IBU } \\
\text { PAR }\end{array}\right.$ & $\left.\begin{array}{l}0.4 \\
4.0\end{array}\right\}$ & B \\
\hline $\begin{array}{l}17 \\
18 \\
19\end{array}$ & $\begin{array}{l}52 \\
52 \\
49\end{array}$ & $\begin{array}{l}\mathbf{F} \\
\mathbf{F} \\
\mathbf{F}\end{array}$ & $\begin{array}{l}10 \\
20 \\
10\end{array}$ & $\begin{array}{l}\text { III } \\
\text { III } \\
\text { III }\end{array}$ & $\begin{array}{l}16 \\
21 \\
30\end{array}$ & $\begin{array}{l}50 \\
50 \\
40\end{array}$ & $\begin{array}{r}50 \\
100 \\
60\end{array}$ & $\begin{array}{l}\mathbf{2} \\
\mathbf{3} \\
\mathbf{3}\end{array}$ & $\begin{array}{l}3 \\
3 \\
4\end{array}$ & $\begin{array}{l}\text { OXY } \\
\text { IND } \\
\text { ASP }\end{array}$ & $\begin{array}{l}0.2 \\
0.075 \\
4.8\end{array}$ & $\begin{array}{l}\mathbf{B} \\
\mathbf{A} \\
\mathbf{B}\end{array}$ \\
\hline 20 & 47 & $\mathbf{F}$ & 1 & III & 25 & 60 & 70 & 4 & 4 & $\left\{\begin{array}{l}\text { SAL } \\
\text { IBU }\end{array}\right.$ & $\left.\begin{array}{l}4.0 \\
0.6\end{array}\right\}$ & A \\
\hline 21 & 45 & $\mathbf{F}$ & 2 & III & 19 & 80 & 60 & 4 & 2 & $\left\{\begin{array}{l}\text { PHE } \\
\text { IBU }\end{array}\right.$ & $\left.\begin{array}{l}0.2 \\
0.6\end{array}\right\}$ & A \\
\hline $\begin{array}{l}22 \\
23\end{array}$ & $\begin{array}{l}54 \\
38\end{array}$ & $\begin{array}{l}\mathbf{F} \\
\mathbf{F}\end{array}$ & $\begin{array}{r}10 \\
3\end{array}$ & $\begin{array}{l}\text { III } \\
\text { IV }\end{array}$ & $\begin{array}{l}36 \\
22\end{array}$ & $\begin{array}{l}70 \\
70\end{array}$ & $\begin{array}{r}70 \\
110\end{array}$ & $\begin{array}{l}2 \\
4\end{array}$ & $\begin{array}{l}4 \\
4\end{array}$ & $\begin{array}{l}\text { IND } \\
\text { IND }\end{array}$ & $\begin{array}{l}0.075 \\
0.175\end{array}$ & $\begin{array}{l}\mathbf{A} \\
\mathbf{B}\end{array}$ \\
\hline 24 & 61 & $\mathbf{M}$ & 5 & IV & 9 & 120 & 120 & 3 & 4 & $\begin{array}{l}\text { PHE } \\
\text { FLU }\end{array}$ & $\left.\begin{array}{l}0.3 \\
0.4\end{array}\right\}$ & B \\
\hline 25 & 58 & $\mathbf{M}$ & 2 & I & 8 & 115 & 90 & 4 & 4 & IND & 0.175 & B \\
\hline 26 & 63 & $\mathbf{F}$ & 10 & III & 17 & 50 & 40 & 4 & 4 & $\left\{\begin{array}{l}\text { ASP } \\
\text { IBU }\end{array}\right.$ & $\left.\begin{array}{l}1.8 \\
1.2\end{array}\right\}$ & A \\
\hline 27 & 47 & $\mathbf{M}$ & 10 & IV & 2 & 90 & 100 & 4 & 4 & IND & 0.1 & B \\
\hline 28 & 56 & $\mathbf{F}$ & 13 & III & 46 & 80 & 75 & 4 & 3 & $\left\{\begin{array}{l}\text { IND } \\
\text { IBU }\end{array}\right.$ & $\left.\begin{array}{l}0.075 \\
1.2\end{array}\right\}$ & B \\
\hline 29 & 51 & $\mathrm{~F}$ & 7 & III & 25 & 75 & 100 & 4 & 4 & IND & 0.1 & $\mathbf{A}$ \\
\hline 30 & 55 & $\mathbf{F}$ & 17 & III & 25 & 70 & 70 & 3 & 3 & $\left\{\begin{array}{l}\text { ASP } \\
\text { PAR }\end{array}\right.$ & $\left.\begin{array}{l}1.5 \\
4.0\end{array}\right\}$ & A \\
\hline 31 & 57 & $\mathbf{F}$ & 11 & III & 25 & 60 & 75 & 3 & 4 & IBU & 1.2 & $\mathbf{A}$ \\
\hline 32 & 44 & $\mathbf{M}$ & 9 & II & 42 & 50 & 60 & 3 & 2 & $\left\{\begin{array}{l}\text { IND } \\
\text { IBU }\end{array}\right.$ & $\left.\begin{array}{l}0.1 \\
1.2\end{array}\right\}$ & A \\
\hline $\begin{array}{l}33 \\
34 \\
35 \\
36 \\
37 \\
38 \\
39 \\
40\end{array}$ & $\begin{array}{l}69 \\
61 \\
30 \\
26 \\
52 \\
57 \\
53 \\
65\end{array}$ & $\begin{array}{l}\mathbf{F} \\
\mathbf{F} \\
\mathbf{F} \\
\mathbf{F} \\
\mathbf{F} \\
\mathbf{F} \\
\mathbf{F} \\
\mathbf{M}\end{array}$ & $\begin{array}{r}45 \\
2 \\
3 \\
2 \\
6 \\
19 \\
4 \\
1\end{array}$ & $\begin{array}{l}\text { III } \\
\text { III } \\
\text { III } \\
\text { II } \\
\text { III } \\
\text { III } \\
\text { III } \\
\text { II }\end{array}$ & $\begin{array}{l}46 \\
15 \\
27 \\
24 \\
27 \\
11 \\
51 \\
15\end{array}$ & $\begin{array}{r}40 \\
160 \\
55 \\
65 \\
70 \\
100 \\
0 \\
110\end{array}$ & $\begin{array}{r}75 \\
150 \\
65 \\
55 \\
70 \\
60 \\
50 \\
100\end{array}$ & $\begin{array}{l}4 \\
3 \\
2 \\
2 \\
2 \\
4 \\
4 \\
3\end{array}$ & $\begin{array}{l}4 \\
3 \\
2 \\
2 \\
4 \\
4 \\
2 \\
4\end{array}$ & $\begin{array}{l}\text { ASP } \\
\text { IND } \\
\text { IND } \\
\text { ASP } \\
\text { IBU } \\
\text { COD } \\
\text { IND } \\
\text { ASP }\end{array}$ & $\begin{array}{l}3 \cdot 6 \\
0 \cdot 3 \\
0 \cdot 125 \\
3 \cdot 6 \\
1 \cdot 2 \\
8 \text { Tabs. } \\
0 \cdot 25 \\
3 \cdot 6\end{array}$ & $\begin{array}{l}\mathbf{B} \\
\mathbf{B} \\
\mathbf{B} \\
\mathbf{A} \\
\mathbf{B} \\
\mathbf{B} \\
\mathbf{A} \\
\mathbf{A}\end{array}$ \\
\hline
\end{tabular}

* Steinbrocker, Traeger, and Batterman (1949)

$4=$ Very severe. § ASP $=$ Aspirin

COD = Tabs codeine co. FLU = Flufenamic acid IBU = Ibuprofen

IND = Indomethacin

MEF $=$ Mefenamic acid OXY $=$ Oxyphenbutazone PAR $=$ Paracetamol
PHE PHE = Phenylbutazone I A = Pentazocine-Placebo $\mathrm{A}=$ Pentazocine-Placebo
$\mathbf{B}=$ Placebo-Pentazocine 
TRIAL DESIGN

The trial was of the double-blind cross-over type, each patient receiving one $25 \mathrm{mg}$. tablet of pentazocine ('Fortral') 4-hourly by day and two $25 \mathrm{mg}$. tablets on retiring at night for 7 days and identical placebo tablets for another week. Patients were randomly allocated to initial pentazocine or placebo treatment periods (Table I), and were carefully instructed to continue their current analgesic anti-inflammatory drug therapy in unaltered dosage.

\section{METHOD OF ASSESSMENT}

Each patient was assessed immediately before starting the trial and after each treatment period by a single observer. Patients were asked to rate pain and stiffness separately on a five-point scale $(0=$ absent, $1=$ mild, $2=$ moderate, $3=$ severe, $4=$ very severe). The articular index of joint tenderness was assessed by the method of Ritchie, Boyle, McInnes, Jasani, Dalakos, Greiveson, and Buchanan (1968), and grip strength was measured in each hand using a standard dynamometer cuff (Wright, 1959). At the completion of 2 weeks' treatment, patients were asked whether the addition of tablets had altered symptoms of pain, and preference was recorded as a preference for the first or second week of therapy or as no difference. Sideeffects were recorded if they were volunteered in response to the standard question at the end of each assessment: 'How does your present treatment suit you?' Finally, any special comments of the patient or examining physician were noted and patients were asked to return the trial tablet bottles at the end of each treatment period.

\section{Results}

Five out of the forty patients failed to complete the study. Three failed to return for assessment after the first week of therapy (two on pentazocine, one on placebo) and two after the second week (one on pentazocine and one on placebo). Only the remaining 35 patients who completed the trial are included in the analysis of results.

Analysis of the treatment order groups showed them to be comparable with respect to age, sex, duration of disease, radiological stage of disease, articular index, grip strength, and severity of initial subjective pain and joint stiffness. They were also comparable with respect to concurrent analgesic antiinflammatory drug therapy (Table I).

\section{SUBJECTIVE PAIN}

The numbers of patients showing changes in subjec- $\mathbb{\mathbb { D }}$ tive pain score are summarized in Table II. Eighteen patients (51 per cent.) showed some improvement in pain score during the study, thirteen (37 per cent.) remained the same, and four (12 per cent.) became $\vec{\omega}$ worse. Although thirteen patients had a better pain $\stackrel{\sigma}{\mathscr{Q}}$ score while on placebo than pentazocine compared with four who had a better score while on pentazocine, $\dot{\omega}$ the difference is not statistically significant $(P>0.05)$. ? Further analysis showed that the order of administration of treatment did not influence the distribution of change in pain scores.

\section{JOINT STIFFNESS}

The number of patients showing changes in joint stiffness score for each treatment period are shown in Table III: 22 patients (63 per cent.) had the same change in stiffness score with pentazocine as with placebo, twelve registering no change with either; patients did better while on pentazocine; seven dif better while on placebo. Order of treatment did not influence the distribution of change in stiffness scores.

\section{ARTICULAR INDEX}

The mean ( \pm S.E.M.) of the articular index was 25.5 을 $( \pm 3 \cdot 5)$ for patients in Group A (Pentazocine-Placebo) and $24.2( \pm 4.5)$ for patients in Group B (PlaceboPentazocine) before starting treatment. After the first week of the trial the means $( \pm$ S.E.M. $)$ were $27 \cdot 3( \pm 4 \cdot 4)$ for Group A and $21.7( \pm 3 \cdot 8)$ for Group B, and after the second week $22 \cdot 3( \pm 4 \cdot 1)$ for Group $A$ and $24 \cdot 1$ $( \pm 4 \cdot 1)$ for Group $B$. The differences are not significant and the order of administration did not influence the distribution of change in the articular index. The

Table II Numbers of patients showing changes in subjective pain score

\begin{tabular}{|c|c|c|c|c|c|c|c|c|}
\hline \multirow{2}{*}{ Treatment } & \multirow{2}{*}{$\begin{array}{l}\text { Change in } \\
\text { pain score }\end{array}$} & \multicolumn{7}{|c|}{ Placebo } \\
\hline & & -1 & 0 & +1 & +2 & +3 & +4 & Total \\
\hline Pentazocine & $\begin{array}{r}-1 \\
0 \\
+1 \\
+2 \\
+3 \\
+4\end{array}$ & $\begin{array}{l}1 \\
- \\
- \\
-\end{array}$ & $\begin{array}{r}3 \\
13 \\
3 \\
- \\
- \\
-\end{array}$ & $\begin{array}{r}7 \\
1 \\
- \\
- \\
-\end{array}$ & $\begin{array}{l}- \\
- \\
- \\
-\end{array}$ & $\begin{array}{r}-1 \\
-1 \\
2 \\
1 \\
1\end{array}$ & $\begin{array}{l}E \\
z \\
-\end{array}$ & $\begin{array}{r}4 \\
21 \\
4 \\
4 \\
1 \\
1\end{array}$ \\
\hline Total patient & & 1 & 19 & 8 & 2 & 5 & - & 35 \\
\hline
\end{tabular}


Table III Numbers of patients showing changes in subjective joint stiffness score

\begin{tabular}{|c|c|c|c|c|c|c|c|}
\hline \multirow[t]{2}{*}{ Treatment } & \multirow{2}{*}{$\begin{array}{l}\text { Change } \\
\text { in joint } \\
\text { stiffness score }\end{array}$} & \multicolumn{6}{|c|}{ Placebo } \\
\hline & & -1 & 0 & +1 & +2 & +3 & Total \\
\hline Pentazocine & $\begin{array}{r}-1 \\
0 \\
+1 \\
+2 \\
+3 \\
\end{array}$ & ${ }^{5}=$ & $\begin{array}{r}3 \\
12 \\
2 \\
3 \\
-\end{array}$ & $\begin{array}{r}- \\
-3 \\
1 \\
-\end{array}$ & $\begin{array}{l}- \\
- \\
1 \\
-\end{array}$ & $\begin{array}{r}-1 \\
-1 \\
1\end{array}$ & $\begin{array}{r}8 \\
13 \\
7 \\
6 \\
1\end{array}$ \\
\hline Total patients & & 5 & 20 & 4 & 3 & 3 & 35 \\
\hline
\end{tabular}

$+=$ less stiffness after therapy.

- = more stiffness after therapy.

Table IV Numbers of patients showing changes in articular index

\begin{tabular}{|c|c|c|c|c|c|c|c|}
\hline \multirow[t]{2}{*}{ Treatment } & \multirow{2}{*}{$\begin{array}{l}\text { Change in } \\
\text { articular } \\
\text { index }\end{array}$} & \multicolumn{6}{|c|}{ Placebo } \\
\hline & & $t>15$ & $+5-15$ & $\pm<5$ & $-5-15$ & $->15$ & Total \\
\hline Pentazocine & $\begin{array}{l}+>15 \\
+5-15 \\
+<5 \\
-5-15 \\
->15\end{array}$ & $\begin{array}{l}= \\
\bar{Z}\end{array}$ & $\begin{array}{l}1 \\
1 \\
1 \\
-\end{array}$ & $\begin{array}{r}1 \\
6 \\
8 \\
3 \\
-\end{array}$ & $\begin{array}{l}-1 \\
8 \\
4 \\
-\end{array}$ & $\frac{-}{1}$ & $\begin{array}{r}2 \\
8 \\
17 \\
8 \\
-\end{array}$ \\
\hline Total patients & & - & 3 & 18 & 13 & 1 & 35 \\
\hline
\end{tabular}

$+=$ more tenderness after therapy.

$-=$ less tenderness after therapy.

Table V Mean ( \pm S.E.M.) grip strength for right and left hands before and during trial treatment

Mean ( \pm S.E.M.) grip strength at assessment $(\mathrm{mm} . \mathrm{Hg})$

\begin{tabular}{|c|c|c|c|c|c|c|}
\hline \multirow{2}{*}{$\begin{array}{l}\text { Treatment order } \\
\text { group }\end{array}$} & \multicolumn{2}{|l|}{ Initial } & \multicolumn{2}{|c|}{1 st week } & \multicolumn{2}{|c|}{ 2nd week } \\
\hline & Right & Left & Right & Left & Right & Left \\
\hline (A) Pentazocine-Placebo & $\begin{array}{l}74 \\
( \pm 8)\end{array}$ & $\begin{array}{l}80 \\
( \pm 8)\end{array}$ & $\begin{array}{l}79 \\
( \pm 8)\end{array}$ & $\begin{array}{l}80 \\
( \pm 6)\end{array}$ & $\begin{array}{l}81 \\
( \pm 8)\end{array}$ & $\begin{array}{l}88 \\
( \pm 9)\end{array}$ \\
\hline (B) Placebo-Pentazocine & $\begin{array}{l}83 \\
( \pm 9)\end{array}$ & $\begin{array}{l}84 \\
( \pm 8)\end{array}$ & $\begin{array}{l}81 \\
( \pm 7)\end{array}$ & $\begin{array}{l}81 \\
( \pm 6)\end{array}$ & $\begin{array}{l}76 \\
( \pm 7)\end{array}$ & $\begin{array}{l}80 \\
( \pm 7)\end{array}$ \\
\hline
\end{tabular}

numbers of patients showing changes in articular index are shown in Table IV. The change in articular index was less than five in eighteen patients (51 per cent.) on placebo and in seventeen (49 per cent.) on pentazocine. Fourteen patients ( 40 per cent.) had a reduction in articular index of five or more while on placebo compared with eight ( 23 per cent.) while on pentazocine and three ( 9 per cent.) had an increase of five or more while on placebo compared with ten ( 28 per cent.) while on pentazocine. Of the 27 patients showing a change in articular index of five or more during one of the treatment periods, five recorded the same change on both treatments, eighteen had a better score while on placebo, and four a better score while on pentazocine, a difference which is statistically significant $\left(\chi^{2}=7.6 ; \mathrm{P}<0.01\right)$.
GRIP STRENGTH

The mean ( \pm S.E.M.) values for grip strength in left and right hands before and after therapy are shown in Table V. The differences were not significant $(P>$ 0.05 ) and there was no order effect. More detailed analysis of numbers of patients registering changes in grip strength (Table VI) also failed to show significant changes.

\section{TREATMENT PREFERENCE}

Thirteen patients (37 per cent.) had no preference for either treatment, seven patients ( 20 per cent.) preferred pentazocine, and fifteen (43 per cent.) preferred placebo. This difference is not significant $(P>0.05)$, and further analysis showed that the order of administration did not effect treatment preference. 
Table VI Numbers of patients showing changes in grip strength

\begin{tabular}{|c|c|c|c|c|c|c|c|c|c|c|c|c|c|}
\hline \multirow{3}{*}{ Treatment } & \multirow{3}{*}{$\begin{array}{l}\text { Change in } \\
\text { grip strength } \\
\text { (mm. Hg) }\end{array}$} & \multicolumn{12}{|c|}{ Placebo } \\
\hline & & \multicolumn{2}{|c|}{$->20$} & \multicolumn{2}{|c|}{$-11-20$} & \multicolumn{2}{|c|}{$\pm<10$} & \multicolumn{2}{|c|}{$+11-20$} & \multicolumn{2}{|c|}{$+>20$} & \multicolumn{2}{|c|}{ Total } \\
\hline & & $R$ & $L$ & $R$ & $L$ & $R$ & $L$ & $R$ & $L$ & $R$ & $L$ & $R$ & $L$ \\
\hline Pentazocine & $\begin{array}{l}->20 \\
-11-20 \\
\pm<10 \\
+11-20 \\
+>20\end{array}$ & $\begin{array}{l}2 \\
\frac{1}{1} \\
-\end{array}$ & $\frac{\frac{1}{1}}{1}$ & $\begin{array}{l}4 \\
1 \\
2 \\
1 \\
-\end{array}$ & $\begin{array}{l}\frac{-}{2} \\
-\end{array}$ & $\begin{array}{l}\frac{1}{8} \\
1 \\
-\end{array}$ & $\begin{array}{r}2 \\
4 \\
13 \\
3 \\
1\end{array}$ & $\frac{\frac{1}{2}}{2}$ & $\frac{-}{1}$ & $\begin{array}{l}- \\
1 \\
1 \\
2 \\
4\end{array}$ & $\frac{\frac{1}{3}}{2}$ & $\begin{array}{r}8 \\
3 \\
13 \\
5 \\
6\end{array}$ & $\begin{array}{r}4 \\
6 \\
17 \\
4 \\
4\end{array}$ \\
\hline Total patients & & 4 & 3 & 8 & 2 & 10 & 23 & 5 & 1 & 8 & 6 & 35 & 35 \\
\hline
\end{tabular}

Table VII Side-effects

\begin{tabular}{|c|c|c|c|c|c|c|c|}
\hline Treatment & $\begin{array}{l}\text { Dizziness } \\
\text { or light- } \\
\text { headedness }\end{array}$ & Drowsiness & Sweating & Nausea & Vomiting & Constipation & $\begin{array}{l}\text { Miscellaneous } \\
\text { abdominal pain, } \\
\text { anorexia, boils }\end{array}$ \\
\hline $\begin{array}{l}\text { Pentazocine } \\
\text { Placebo }\end{array}$ & $\begin{array}{l}7 \\
1\end{array}$ & $\begin{array}{l}3 \\
1\end{array}$ & 3 & $\begin{array}{l}3 \\
3\end{array}$ & $\begin{array}{l}2 \\
2\end{array}$ & $\begin{array}{l}1 \\
1\end{array}$ & $\begin{array}{l}2 \\
3\end{array}$ \\
\hline
\end{tabular}

\section{SIDE-EFFECTS}

The side-effects encountered during the course of the trial are tabulated (Table VII). 21 patients (60 per cent.) complained of side-effects. Eighteen (51 per cent.) had side-effects with pentazocine compared with eight (23 per cent.) with placebo. This difference is statistically significant $(P<0.05)$. Five patients (14 per cent.) had side-effects with both treatments. Therapy had to be discontinued because of the severity of side-effects in four patients ( 3 pentazocine, 1 placebo). Thirteen patients ( 37 per cent.) had sideeffects only with pentazocine, compared with three (9 per cent.) who only had side-effects with placebo $(P<0.05)$. The order of administration of drugs did not affect the incidence or the nature of side-effects, but the sex of the patients may have done so. Of all 24 female patients, eighteen ( 75 per cent.) complained of side-effects either after pentazocine or placebo or both, compared to three of the eleven males ( 27 per cent.) $(P<0.05)$.

Table VIII shows the relationship between drug preference and side-effects. Of fourteen patients with no side-effects, one preferred pentazocine, five preferred placebo, and eight had no preference. Of the eighteen patients who experienced side-effects with pentazocine, five preferred pentazocine, eight preferred placebo, and five had no preference. In como parison, of the eight patients who experienced sides effects with placebo, three preferred pentazocine, four preferred placebo, and one had no preference.

\section{Discussion}

Clinical improvement on placebo tablets during the course of drug trials in rheumatoid arthritis is well documented (Donnelly, Lloyd, and Campbell, 1967; Boardman and Hart, 1967a; Co-operating Clinics, 1967) and may be partly attributable to placebo effects. Although such effects are usually assumed to be of short duration, there is at least one report of the effectiveness of placebo therapy over many months (Traut and Passarelli, 1959). In the present study about one-third of patients already receiving active analgesic anti-inflammatory drugs registered improvement both in subjective assessment of joint pain and stiffness and in semi-objective assessment indices such as the articular index and grip strength on receiving added placebo therapy. It is conceivable that concurrently administered effective analgesic

Table VIII Relationship of patient preference to side-effects

\begin{tabular}{|c|c|c|c|c|c|}
\hline \multirow[b]{2}{*}{ Preference } & \multicolumn{5}{|c|}{ Occurrence of side-effects } \\
\hline & $\begin{array}{l}\text { Placebo } \\
\text { only }\end{array}$ & $\begin{array}{l}\text { Pentazocine } \\
\text { only }\end{array}$ & $\begin{array}{l}\text { Pentazocine } \\
\text { and placebo }\end{array}$ & $\begin{array}{l}\text { No side- } \\
\text { effects }\end{array}$ & Total \\
\hline $\begin{array}{l}\text { Pentazocine } \\
\text { Placebo } \\
\text { No preference }\end{array}$ & $\begin{array}{l}1 \\
2 \\
-\end{array}$ & $\begin{array}{l}3 \\
6 \\
4\end{array}$ & $\begin{array}{l}2 \\
2 \\
1\end{array}$ & $\begin{array}{l}1 \\
5 \\
8\end{array}$ & $\begin{array}{r}7 \\
15 \\
13\end{array}$ \\
\hline Total patients & 3 & 13 & 5 & 14 & 35 \\
\hline
\end{tabular}


therapy may have resulted in an enhancement of the placebo response, but it is interesting to note that the effectiveness of placebo was not related to order of administration in this trial. In some trials (e.g. Fearnley, Lackner, Meanock, and Bywaters, 1956), drugs are shown to be 'effective' only when administered first, and it has previously been demonstrated that placebo becomes a more effective medication when administered as a second dose after an active test drug than after an ineffective one (Sunshine, Laska, Meisner, and Morgan, 1964; Batterman, 1965, 1966; Kantor and others, 1966; Batterman and Lower, 1968). These investigators have suggested that this was a drawback to cross-over studies. In the present trial it is clear that the addition of oral pentazocine was not significantly different from placebo in its effect on joint pain, joint stiffness, grip strength, or mean articular index. In addition, there was no significant difference in patient preference for either treatment. Although 37 per cent. of patients were in the same category of the articular index while on both treatments, there was a significant difference in the number of patients who did better with regard to articular index while on placebo compared with those who did better while on pentazocine. Since this is a unique observation with regard to the efficacy of the two treatments, it would seem unlikely to be other than a chance occurrence.

Joyce (1968) has emphasized the importance of examining the 'improvement rate' on placebo therapy. In this study placebo resulted in $\mathbf{4 0}$ per cent. of patients showing significant improvement in articular index and 43 per cent. expressing preference for placebo; these results are very similar to the 40 per cent. placebo response expected by Batterman and Grossman (1955) and well within the range of 21 to 59 per cent. for placebo responses found by Beecher (1955) in a wide survey. The patients entering our trial were selected as having severe and intractable pain. The effectiveness of placebos has been shown to increase with increased stress (Beecher, 1956), but the ability to discriminate between placebo and active analgesic has also been shown to be greater when there is more initial pain (Hill and Turner, 1969).

There was a significantly greater incidence of sideeffects during the pentazocine treatment. Nausea, vomiting, and constipation occurred with equal frequency during pentazocine and placebo therapy, while dizziness, light-headedness, drowsiness, and sweating, which were most frequent side-effects encountered, were confined largely to the pentazocine treatment period. Short-term trials involving small numbers of patients are not adequate for assessing the true incidence or clinical importance of side-effects, but the 51 per cent. overall incidence of side-effects in patients taking pentazocine in this study is high by any standard and certainly higher than that found in previous trials of oral pentazocine (Kantor and others, 1966; Gürtler and Steiger, 1967) in which single doses of 35 and $50 \mathrm{mg}$. were used. The overall incidence of side-effects was 8 per cent. after single oral doses of pentazocine in the only previously reported trial in which oral pentazocine, 35 and 50 mg., was given to patients with rheumatoid arthritis (Gürtler and Steiger, 1967). Unfortunately these were only three patients among fifty with a variety of conditions and individual findings were not reported. In one trial in which oral pentazocine 50 to $100 \mathrm{mg}$. four times a day was administered to 72 patients with osteoarthrosis in general practice, the incidence and pattern of side-effects were comparable to those found in this study (General Practitioner Research Group, 1971). Our study seems to confirm the findings of Kantor and others (1966) that side-effects with pentazocine are more frequent in females. Treadwell, Sever, Savage, and Copeman (1964) found that this was true for corticosteroid and corticotrophin sideeffects and Boardman and Hart (1967b) have shown the same for indomethacin side-effects in patients with rheumatoid arthritis.

Despite isolated reports of abuse and dependence after oral administration (Hart, 1969; Alarçón, Gelfond, and Alarçón, 1971), pentazocine would seem to be relatively free from the risk of addiction (W.H.O. Technical Reports, 1966, 1969, 1970; Chambers, Inciardi, and Stephens, 1971). It is undoubtedly an effective major analgesic (Today's Drugs, 1970) which is useful for relieving pain after operations (Kantor and others, 1966), in patients with cancer (Beaver and others, 1968) and after myocardial infarction (Scott and Orr, 1969). It is likely that some patients with rheumatoid arthritis will be able to tolerate large oral doses or parenteral pentazocine and derive benefit from the addition of this drug to anti-inflammatory drug therapy when analgesia is inadequate. The results of this trial, however, indicate that the addition of a relatively small dose of oral pentazocine to the drug regimen of patients with rheumatoid arthritis who have inadequate pain relief from conventional anti-inflammatory analgesics is unlikely to be worthwhile. Similar limitations may apply to other potent centrally-acting analgesics, the value of which has never been demonstrated in patients with rheumatoid arthritis.

\section{Summary}

A double-blind cross-over trial is reported of oral pentazocine $25 \mathrm{mg}$. 4-hourly by day plus $50 \mathrm{mg}$. at night versus identical placebo tablets. Each was administered for 7 days to forty hospital out-patients with rheumatoid arthritis receiving non-steroidal anti-inflammatory analgesic drugs in steady dosage with inadequate pain relief. Beneficial effects were noted in at least one-third of the patients, but there was no significant difference between pentazocine and 
placebo as judged by patient preference, joint pain, joint stiffness, grip strength, or mean articular index. There was a significantly higher incidence of sideeffects with pentazocine than placebo. The significance of these findings in relation to the management of rheumatoid arthritis is discussed and it is concluded that oral pentazocine used in the manner and dosage employed in this study is unlikely to be of value in the management of ambulant patients with this disease.

The authors wish to acknowledge the financial support of the Arthritis and Rheumatism Council for Research in Great Britain. One of us (G.N.) was in receipt of a CIBA Research Fellowship.

\section{References}

Alcarçón, R. D., Gelfond, S. D., ANd Alcarçón, G. S. (1971) Johns Hopk. med. J., 129, 311 (Parenteral and oral pentazocine abuse)

Archer, S., Albertson, N. F., Harris, L. S., Pierson, A. K., Bird, J. G., Keats, A. S., Telford, J., and PaPAdOPOUlos, C. N. (1962) Science, 137, 541 (Narcotic antagonists as analgesics)

Batterman, R. C. (1965) Curr. Ther. Res., 7, 639 (Methodology of analgesic evaluation: experience with orphenadrine citrate compound)

(1966) J. new Drugs, 6, 137 (Persistence of responsiveness with placebo therapy following an effective drug trial)

- - AND Grossman, A. J. (1955) J. Amer. med. Ass., 159, 1619 (Effectiveness of salicylamide as an analgesic and anti-rheumatic agent)

- AND LOWER, W. R. (1968) Curr. Ther. Res., 10, 136 (Placebo responsiveness; influence of previous therapy)

Beaver, W. T. (1968) Fed. Proc., 27, 653 (Comparison of the analgesic effects of oral and intramuscular pentazocine in patients with cancer)

- - W Allenstein, S. L., Houde, R. W., and Rogers, A. (1968) Clin. Pharm. Ther., 9, 582 (A clinical comparison of the effects of oral and intramuscular administration of analgesics: Pentazocine and phenazocine)

Beckett, A. H., Taylor, J. F., And Kourounakis, P. (1970) J. Pharm. Pharmacol., 22, 123 (The absorption, distribution and excretion of pentazocine in man after oral and intravenous administration)

BeECHER, H. K. (1955) J. Amer. med. Ass., 159, 1602 (The powerful placebo)

- (1956) Amer. J. Physiol., 187, 163 (Evidence for increased effectiveness of placebos with increased stress)

BoARdman, P. L., AND HART, F. Dudley (1967a) Brit. med. J., 4, 264 (Clinical measurement of the antiinflammatory effects of salicylates in rheumatoid arthritis)

- _ - (1967b) Ann. rheum. Dis., 26, 127 (Side-effects of Indomethacin)

Chambers, C. D., Inciardi, J. A., ANd Stephens, R. C. (1971) H.S.M.H.A. Hlth Rep., 86, 627 (A critical review of pentazocine abuse)

Co-operating Clinics Committee of the American Rheumatism Association (1967) Clin. Pharm. Ther., 8, 11 (A three-month trial of indomethacin in rheumatoid arthritis with special reference to analysis and inference)

DAvid-Chaussé, J., AND LAPORTE, G. (1970) Bordeaux méd., 3, 1151 (L'administration du fortal en rhumatologie)

DonNelly, P., LlOYd, K., AND CAMPBell, H. (1967) Brit. med. J., 1, 69 (Indomethacin in rheumatoid arthritisan evaluation of its anti-inflammatory and side effects)

Drug Ther. Bull. (1966) 4, 21 (Drugs for rheumatoid arthritis)

Fearnley, G. R., Lackner, R., Meanock, R. I., AND Bywaters, E. G. L. (1956) Ann. rheum. Dis., 15, 134 (Pilot study of intra-articular procain and hydrocortisone acetate in rheumatoid arthritis)

Filler, W. W., AND FilleR, N. W. (1966) Obstet. and Gynec., 28, 224 (Effect of a potent non-narcotic analgesic agent (Pentazocine) on uterine contractility and fetal heart rate)

Frankendal, B., AND KJellgRen, O. (1971) Cancer, 27, 842 (Severe pain in gynecologic cancer. Trial of pentazocine, morphine and a placebo)

Fremont-Smith, P., AND Bayles, T. B. (1965) J. Amer. med. Ass., 192, 1133 (Salicylate therapy in rheumatoid arthritis)

General Practitioner Research Group (1971) Practitioner, 208, 557 (Report No. 169: Two analgesics compared in osteoarthrosis)

Gürtler, J., AND Steiger, J. (1967) Praxis, 56, 1074 (Double blind trial of an analgesic substance (Pentazocine))

HART, F. Dudley (1968) Brit. med. J., 3, 635 (Control of pain in the rheumatic disorders)

HART, R. H. (1969) Lancet, 2, 690 (Pentazocine addiction)

Hill, R. C., AND TURNer, P. (1969) J. clin. Pharmacol., 9, 321 (Importance of initial pain in post-operative assessment of analgesic drugs)

JOYCE, C. R. B. (1968) 'Psychological factors in the controlled evaluation of therapy in psychopharmacology', in 'Psychological Dimensions and Perspectives', ed. C. R. B. Joyce, p. 215. Tavistock Publications, London

Kantor, T. G., Sunshine, A., Laska, E., Meisner, M., AND Hopper, M. (1966) Clin. Pharm. Ther., 7, 447 (Oral analgesic studies: pentazocine hydrochloride, codeine, aspirin, and placebo and their influence on response to placebo)

MitcheLl, M. T. (1963) Minnesota Med., 46, 1230 (Evaluation of a new non-narcotic analgesic in obstetrics) 
Ritchie, D. M., Boyle, J. A., McInnes, J. M., Jasant, M. K., Dalakos, T. G., Grieveson, P., and Buchanan, W. W. (1968) Quart. J. Med., 37, 393 (Clinical studies with an articular index for the assessment of joint tenderness in patients with rheumatoid arthritis)

Ropes, M. W., Bennett, G. A., Cobb, S., JACox, R., And Jessar, R. A. (1959) Ann. rheum. Dis., 18, 49 (1958 revision of diagnostic criteria for rheumatoid arthritis)

ScorT, M. E., AND ORR, R. (1969) Lancet, 1, 1065 (Effects of Diamorphine, Methadone, Morphine, and Pentazocine in patients with suspected acute myocardial infarction)

Sunshine, A., Laska, E., Meisner, M., And Morgan, S. (1964) Clin. Pharm. Ther., 5, 699 (Analgesic studies of indomethacin as analyzed by computer techniques)

TAYLOR, I. (1971) Brit. J. clin. Pract., 25, 27 (Clinical trial comparing pentazocine with pethidine and morphine in severe ishaemic limb pain)

TODAY's Drugs (1970) Brit. med. J., 2, 409 (Pentazocine)

Traut, E. F., AND Passarelli, E. W. (1959) Illinois med. J., 115, 181 (Placebos in the evaluation of treatment in rheumatic diseases)

Treadwell, B. L. J., Sever, E. D., Savage, O., and Copeman, W. S. C. (1964) Lancet, 1, 1121 (Side-effects of long-term treatment with corticosteroids and corticotrophin)

Vignon, G., Chapuy, P., And Falconnet, M. (1969) Rev. Lyon Méd., 18, No. 12, 5 (Pentazocine in rheumatology)

Winter, C. A. (1966) Fortschr. Arzneimittelforsch. (Progr. Drug Res.), 10, 139 (Non-steroid anti-inflammatory agents)

World Health Organization (1966) Expert Committee on Drug Dependence, W.H.O. Tech. Rep. Ser., 343, 6 (1969) Idem, W.H.O. Tech. Rep. Ser., 407, 23 (1970) Idem, W.H.O. Tech. Rep. Ser., 437, 24

WrIGHT, V. (1959) Clin. Sci., 18, 17 (Some observations on diurnal variation of grip) 